\title{
Education as a Vehicle for Social Reproduction in China?
}

\section{The Relationship Between Meritocratic Education and Social Reproduction, 1978-present}

\author{
Su Chen ${ }^{1, \dagger}$ HALONEN ANNI MARIA ${ }^{2, \dagger}$ Tongfei Liu ${ }^{3, \dagger, *}$
}

\author{
${ }^{1}$ China University of Geosciences (Beijing), Beijing, Beijing, China \\ ${ }^{2}$ Peking University, Beijing, Beijing, China \\ ${ }^{3}$ University of Birmingham, Birmingham, UK \\ ${ }^{*}$ Corresponding author. Email: 1800092046@pku.edu.cn \\ ${ }^{\dagger}$ These authors contributed equally.
}

\begin{abstract}
Most of the theories on education and social reproduction in China focus on how the great changes in China's socioeconomic life have led to the improved quality of meritocratic education. This article attempts to answer whether the education system aiming to provide the nation with meritocracy is the reason for social reproduction. We give a literature review on meritocratic education and social inequality using China as a case study and present our research methods and data sources. We present collective evidence and analytical reasoning, reform in the labour market since 1978, Projects 985 and 211, and privatization of education since the late 1990's. Finally, we argue that there is a negative relationship between meritocratic education and social reproduction.
\end{abstract}

Keywords: Meritocratic education, social reproduction, education system

\section{INTRODUCTION}

In 1978, China changed its education policy to support the reconstruction of the economy and improvement. The college entrance examination was reinstated in 1977 as part of the government priority of meritocratic education. The government distributed more resources to education, especially in rural areas, and formulated a meritocratic education system. Special attention was paid to academic quality in universities. Projects like 985 and 211 were carried out to encourage students to perform better in college entrance examinations. Policy changes led to less enrollment in universities from lower-income- households. This created a public debate about whether exam-oriented education should continue.

Most of the theories concentrating on education and social reproduction in China are focused on explaining how the great changes in China's economic and social life have led to a certain degree of changes in the quality of meritocratic education. In this article, we attempt to answer whether the education system aiming to provide the nation with meritocracy is the reason for social reproduction.

We give a literature review on meritocratic education and social inequality using China as a case study and present our research methods and data sources. We present collective evidence and analytical reasoning, reform in the labour market since 1978, Projects 985 and 211, and privatization of education since the late 1990's. We also compare the Chinese case with Finnish education. Finally, we argue that there is a relationship between meritocratic education and social reproduction.

\section{LITERATURE REVIEW}

\subsection{The Reform in The Labour Market Since 1978}

Driven by international trade, China implemented the “open door" policy in 1978, which expanded its trade with other countries and marked its participation in the competitive domain of world business [1]. Cheap labour caused by the central-planned economy had played a central role in the Chinese economic model until the late 
1990 s, and the growth of the average annual wage of a Chinese worker was stagnant from 1978 to 1997. As the global economy became, progressively integrated pressure rose among individual nation states to improve or maintain their competitiveness in the world economic market. China's centrally planned economy was transformed into a market-oriented economy in the late 1990s, accompanied by policies that de-centralised governmental control and allowed the privatization of originally state-owned enterprises. Labour wages rose and were closely linked to productivity. This is demonstrated by the survey data carried out by Li et al. [2], which showed that wages increased for Chinese workers at all skill levels from 1998 to 2010. Still, the growth rate was in accordance with workers' education levels (6. 5percent and 9. 0percent for workers with low and high education level respectively). The survey data showed a great increase in the percentage of workers who continued their education when they realized that wages were linked to productivity [2]. With the demand for education in Chinese society and the influence of the Globalization Education Reform Movement (GERM), which we explore in the next section, the number of private schools and educational institutions has rapidly increased during the last two decades.

The movement to the post-industrial era diminished the necessity of simple manual labour. It required that people be trained to become knowledge workers who make money to maintain economic competitiveness in the global market [3]. Knowledge-based economic systems commercialized education, which has since led to the social expectation that earning an education is economically rewarding. The market-oriented economy and for-profit education achieved fast economic development for the whole country and allowed the alleged economic trickle-down effect to occur ${ }^{4}$. People's wages have increased from nearly $¥ 1300$ to $¥ 3558$ between 1998 and 2010 in China [2]. This process enables China to become richer as a whole, but the market-oriented economy facilitated the wealth gap ${ }^{4}$. Financial constraints and weakened state capacity have become major concerns that drive the reconstruction and reforms in Chinese society.

The political and economic needs have led the government to implement a wide range of education reforms in the meritocracy-based selection system, including nine-year compulsory education, high school entrance examination, college entrance examination, 985 and 211 projects. The education system in China is based on a meritocratic model, which causes the great commercialization and competition in education at present.

\subsection{Meritocratic Education}

The definition of the first-tier Meritocratic universities is heavily overlapped with the project-211 and the project-985. Project 985 was first put forward by President Jiang Zemin on the anniversary of Peking University in 1998. He claimed that policies in China had created a system for economy and the trade or international trade and education was an important part of the society. The target of the project was to cultivate more talent for modernization in society. 985 is the continuation of the policy of national key universities and key disciplines, and only high-quality universities could be listed in the project. Project 211 perfected the Meritocratic education system. 985 pays more attention to enhancing the whole university's strength, which creates the school's reputation. 211 emphasized subjects, and the development of discipline is not connected to the university. It also provides these college graduates a better chance for employment.

In China, schools recruit students based on their scores, and there are the middle school entrance examination, high school entrance examination, and the foremost college entrance examination. Influenced by the neo-liberal education movements, there are school league tables that divided schools as outstanding and underperforming and increased competition among them. Entering into key or outstanding primary schools means higher opportunities to study in superior, middle schools, superior high schools, and in turn, the first-tier universities in the future. This means the fierce competition of good education resources has even started from children's primary schools. Driven by the hierarchical division of universities, the competition of good education resources in the primary and secondary schooling stage, which is also known as the K12 stage in China, leads the experience of Chinese schooling to be described as being "compelled to excel". As encouraged by Confucius that the one who excels in education should be officials, Chinese people traditionally view education as a tool to achieve social mobility (The Analects, 1999). Thus, attending top-tier universities means to change the life trajectory and achieve social mobility for Chinese people. On the one hand, students in Meritocratic institutions can have the best educational resources, such as laboratories and libraries. On the other hand, students from 985 and 211-universities have more opportunities to be employed with higher economic returns. 
Table 1 The number of colleges since 1954 in China

\begin{tabular}{|c|c|c|c|c|}
\hline Year & $\begin{array}{c}\text { National } \\
\text { Key } \\
\text { Universitie } \\
\text { s }\end{array}$ & $\begin{array}{c}\text { 'seven } \\
\text { five','eigh } \\
\text { t five' key } \\
\text { universitie } \\
\text { s }\end{array}$ & $\begin{array}{c}\text { Project- } \\
211 \\
\text { universitie } \\
\mathrm{s}\end{array}$ & $\begin{array}{c}\text { Project- } \\
985 \\
\text { universitie } \\
\mathrm{s}\end{array}$ \\
\hline 1954 & 6 & & & \\
\hline 1959 & 16 & & & \\
\hline 1960 & 64 & & & \\
\hline 1963 & 67 & & & \\
\hline $\begin{array}{c}\text { the } \\
\text { Cultural } \\
\text { Revolutio } \\
n\end{array}$ & - & & & \\
\hline 1978 & $88+2$ & & & \\
\hline 1979 & 96 & & & \\
\hline 1985 & & $5+3$ & & \\
\hline 1990 & & 11 & & \\
\hline 1996 & & & 2 & \\
\hline 1997 & & & 32 & \\
\hline 1998 & & & 61 & 2 \\
\hline 1999 & & & 92 & 9 \\
\hline 2000 & & & 99 & 12 \\
\hline 2001 & & & & 29 \\
\hline 2002 & & & & 33 \\
\hline 2003 & & & & 34 \\
\hline
\end{tabular}

\subsection{Privatisation of education}

Since the 1980s Chinese economy has experienced significant and sustained growth with an average annual growth rate of 9 to 10 percent. However, the government's investment in education is low. In 1995 investment in education accounted for only 2.41 percent of GDP, which increased slightly in 1999 and 2000 to 2.79 percent and 2.86 percent, respectively. National investment in education declined again in 2004, with only 2.79 percent of GDP allocated to education. In recognition of the importance of basic education for Chinese citizens, primary and secondary schools attract more state funds than higher education. Government financial support for higher education has decreased from 93.5percent in 1990 to 50 percent in 2002.

Zhu Qingfang [5] has conducted surveys on the consumption patterns of urban Chinese and has repeatedly pointed out that the cost of children's education has become a heavy economic burden for parents. More than a third of Chinese urban consumption is spent on education, health insurance, and housing. In 2004, education accounted for 7.8 percent of the total consumption of Chinese urban residents, which is an increase of 41 percent compared with 2000. From 2000 to 2004, spending on education by urban residents increased at an average annual rate of 9 percent. In the past 10 years, Chinese urban residents have paid about 2 trillion yuan to the education sector [5].

Table 2 Proportion of public education in GDP unit: billion $\mathrm{RMB}$

\begin{tabular}{llll}
\hline Year & GDP & Allocation & percentage \\
& & $\begin{array}{l}\text { of } \\
\text { national } \\
\text { education funds }\end{array}$ & $\begin{array}{l}\text { of public } \\
\text { expenditure. }\end{array}$
\end{tabular}

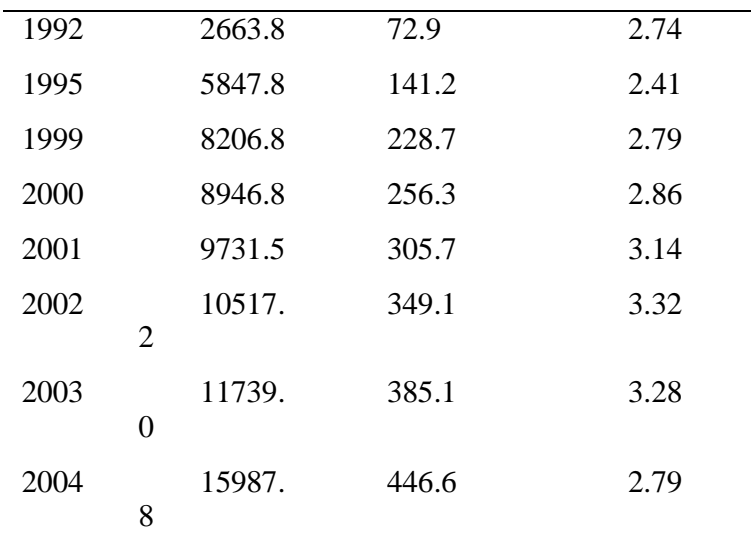

The privatization of Chinese higher education has increased since 1993. On the one hand, the need for a higher qualified workforce and meritocratic selection for education has increased the demand for private education. This applies especially to private supplementary tutoring among primary and secondary students $[6,7]$. This is also called the shadow education system in China. The national policy in the late 1990s encourages and supports individuals, guiding management for individuals to run private schools (CCPCC, 1993). These eventually lead parents to deem that it is necessary to invest in tutoring to supplement to raise their children's scores and so that they can gain a more competitive edge in education selection [7]. On the other hand, it is unavoidable that rich families purchase better quality tutoring for their children. Therefore, this shadow system of education undermines the equality of opportunity in schooling in China [8]. The great competitive edge of a certain group of individuals will squeeze the living space of others. Though education is free and compulsory in the primary and junior secondary stage, it has become more expensive and trend towards Meritocratic education due to private tutoring in China.

\section{RESEARCH METHOD}

The methods used in our study are known as literature analysis and qualitative analysis. We mainly collect and analyze the policy text data to have a more in-depth understanding of the historical process of Chinese education and economic reform since the 1970s. We explore the driving mechanism and influencing factors to 
promote the reform. This paper explores the development and trend of Chinese Meritocratic education and social reproduction.

Through literature research, we can understand the history and current situation of meritocratic-based education and social reproduction and help to determine the research topic. At the same time, it can help observe and visit and form a general impression of the current situation of Chinese education. We get the comparative information of the real data and the panorama of things.

Through an analysis of literature, we can understand Meritocratic education and social reproduction more accurately. Using a series of numbers, tables, and icons to illustrate the problem, we can use various data collection methods to explore the social phenomenon as a whole. We use an inductive method to analyze data and form theory. We grasp the essence and clarify the relationship.

\section{EVIDENCE AND ANALYSIS}

Due to the social ideology, the whole education system was built by the government. In primary school and middle school, the bureau of education distributes textbooks and teachers through the partition of a different region of cities and countryside. Parents who live in cities like Beijing and Shanghai can give their children more chances for a good living, and they can choose to be experts in art or music, but students in rural areas can only enter college to improve their lives [9]. The entrance examination of college and senior high school should be the chance for kids from the countryside to break the reproduction cycle of social status. Currently, the situation is exactly the opposite.

Term 'college entrance examination factory' refers to a special kind of middle school with four characteristics:

- using militarized management

- taking students as a machine for exams

- knowledge teachers taught all relating to exams

- overlooking differences among individuals [10].

College entrance examination factory- mode obviously deviates from the national foundation. The value orientation of education policy has abandoned the basic idea of quality education and has been criticized by the media and education circles. Kang Jian, the former headmaster of Peking University, said that this kind of school is created by and strengthens the typical examoriented education, which harms the comprehensiveness of Chinese schooling. Education is increasingly seen as an investment in China. More and more factory schools aim to increase scores in the entrance examination. Lessadvantaged-family children have increasingly lost their chance for better higher education which has caused anxiety among them.
The anxiety has already spread to primary school. A new popular word $\mathrm{Ji}$ Wa comes up on the Internet, cultivating children in all subjects at a very young age even when they cannot read or write. The first reason is the education anxiety of Chinese parents. They worry about the development of their children and even push themselves into the study and learn mathematics, Chinese, English, and musical instruments with those kids. The competitive environment and limited resources motivate children to extra classes. According to 'the law of hearts queen' put forward by Leigh Van Valen, the way we survive in a more competitive society is to keep the same pace with others, and the way to surpass others to gain achievement is using twice the time. Therefore ' $\mathrm{Ji} \mathrm{Wa}$ ' appears, and parents take kids to learn extra skills to not be eliminated in competition [11].

The current situation is now described by "involution," an academic term re-used and explained by Chinese netizens to portray the intense competition for better educational resources. Human society stagnates or cannot advanced more after reaching a certain form in a development stage. When social resources cannot meet all people's needs, people get more resources through competition. It is the inflation of efforts.

\section{CONCLUSION AND FURTHER DISCUSSION}

In recent decades, China has gone through massive social, economic, and political transitions. This article synthesizes how meritocracy education has transformed into Meritocratic education that the richer can hold more and better educational resources. The marketization and privatization of education, carried out by the global education reform movement, have made students' choice of schools become parents' competition. It is a conflicted goal for schools to foster comprehensive pupils while using an exam-oriented education system. The parents' rights of self-choice and the grading standards of schools enhance the competition both among schools and students. Thus, private tutoring institutions have been boosted to challenge the equality of the Chinese education system.

We compare the privatization of the Chinese education system to other countries such as Finnish education and try to find how can improve the public school to reduce the education privatisation. Before independence in 1917, Finland was ruled by Sweden and Czarist Russia for seven centuries, and the official language was Swedish. After the writer, Elias Lönnrot collected a large number of folk songs in Finland and the Karelia area he 1835 published Kalevala, which is the most significant work in Finnish literature. Kalevala inspired Finnish people's self-confidence and sense of identity with their own language and culture. Finland eventually became independent from Russia in 1917. Because the Finnish language and Finnish characters 
occupy such an important position in the history of Finland, education is also important in Finland.

Finnish education pays special attention to equality and quality. Everyone can get a relatively fair education and enjoy the same quality of educational resources. In most countries, higher education is allocated based on funds' ability to pay tuition fees. But in Finland, investment in basic education, especially in senior students, is the highest globally (with an average of $\$ 8200$ per person).

Finland has a population of 5 million, a land area of 330,000 square kilometers, and a vast area of sparsely populated areas. Finland can hardly bear the consequences of education failure. If Finland gives up these students at the initial stage, then Finland will spend more resources to make up for them after they grow up and enter society. Therefore, Finnish education will never give up any students.

\section{REFERENCES}

[1] Arthur, J., Davies, I., \& Hahn, C. (Eds.). (2008). Sage handbook of education for citizenship and democracy. Sage.

[2] Li, H., Li, L., Wu, B., \& Xiong, Y. (2012). The end of cheap Chinese labor. Journal of Economic Perspectives, 26(4), 57-74.

[3] Ball, S. J. (2017). The education debate. Policy Press.

[4] Bellamy, C. (2000). Modelling electronic. democracy. Democratic governance and new technology, 33-53.

[6] Jia, R., \& Hongbin, L. (2017). The value of Meritocratic education in China. 21st Century China Center Research Paper, (2017-07).

[7] Zhang, W., \& Bray, M. (2018). Equalising schooling, unequalising private supplementary tutoring: access and tracking through shadow education in China. Oxford Review of Education, 44(2), 221-238.

[8] Liu, J., \& Bray, M. (2020). Evolving micro-level processes of demand for private supplementary tutoring: Patterns and implications at primary and lower secondary levels in China. Educational Studies, 46(2), 170-187.

[9] Jizhou Zhang,Shuguang Huang,Besieged college entrance examination: the dilemma of the stratum behind the paradox of the new college entrance examination reform and its solution,2018,v.38;No.414(04):96-102.

[10] Jizhou Zhang,The Anxiety of Social Classes and Opportunity Fairness under the "College Entrance
Examination Factory, Research on Higher Education in China,2015,000(009):33-36.

[11] Huazai Chen,Xiong Xiao,An interpretation of the phenomenon of "educational anxiety" of Chinese parents,Journal of National Institute of Education Administration,2014(02):20-25. 